\title{
Chickpea (Cicer arietinum L.)
}

\author{
Kiran Kumar Sharma, Pooja Bhatnagar-Mathur, and Boddu Jayanand
}

\begin{abstract}
Summary
Chickpea is one of the most important leguminous, cool-season, food crops, cultivated prevalently in the Asian Pacific region. In spite of its nutritional importance, its area of cultivation has been low, with virtually no increase. Conventional breeding has resulted in several important improvements in this crop, and recent advances in biotechnology such as plant tissue culture and genetic transformation can significantly contribute to better sustainability of this important food crop. Here, we describe an efficient Agrobacterium-mediated transformation protocol for chickpea using axillary meristem explants, which results in a high frequency of genetic transformation (70\%) and recovery of valuable transgenic plants. The protocol is significant owing to its high reproducibility and recovery of the transgenics in a relatively short period (90-100 days).
\end{abstract}

Key Words: Chickpea; Cicer arietinum; genetic transformation; hardening; shoot regeneration; tissue culture, rooting of shoots; transgenic plants.

\section{Introduction}

Chickpea (Cicer arietinum L.) is one of the important grain legumes that play a significant role in the nutrition of the rural and urban poor in the developing world. Chickpea is traditionally grown in many parts of the world, including Asia, Africa, Europe, and North and South America, and it contributes $15 \%$ to the world pulse harvest of about 58 million tons annually. Despite significant gains in world pulse production during the last two decades (annual growth rate of $1.9 \%$ ), chickpea production growth has been slow. This slower pace in chickpea production has been the result of various refractory biotic and abiotic constraints such as ascochyta blight (AB), botrytis grey mold (BGM), dry root rot, collar rot, fusarium wilt, pod borer, and abiotic stress like drought and low temperature. The available chickpea germplasm lacks effective resistance for use in developing insect pest-resistant genotypes. 
Classical and modern breeding technologies have resulted in limited success in interchange of the desirable characters in this important pulse crop. However, biotechnological techniques have emerged as a potential supplement to these efforts. Advances in plant tissue culture and genetic transformation methodologies have paved the way for alternative crop improvement and creation of an elite germplasm. However, reliable regeneration and transformation protocols have not emerged, owing to the perceived recalcitrant nature of chickpea toward tissue culture. Although several regeneration and transformation protocols involving somatic embryogenesis and organogenesis have been reported with varying success rates $(\mathbf{1 - 7})$, effective chickpea regeneration has been possible only through use of explants based on cotyledonary nodes or shoot apices derived from seedling explants (3). Asynchronous shoot bud production makes a number of chickpea regeneration systems inefficient for genetic transformation $(\mathbf{8}-\mathbf{1 0})$. In addition, rooting and transplanting of the in vitro recovered chickpea plants have remained a major bottleneck in the application of transformation technology for serious crop improvement programs.

A prerequisite for the in vitro manipulation of a plant species is the availability of an efficient and reproducible plant regeneration system. In chickpea, several shoot regeneration protocols have been reported (3). However, low success rates for recovery of plants make these protocols inefficient for genetic transformation. The protocol detailed here has been optimized using various tissue culture variables in pursuit of an efficient and reproducible transformation and regeneration procedure based on regeneration procedures described earlier (11) for high-frequency genetic transformation (Sharma et al., unpublished results) and recovery of valuable transgenic chickpea plants. The method involves the use of the axillary meristem explant produced by removing the axillary bud and overcoming the apical dominance of the shoot buds. Results are better in terms of regeneration and transformation efficiency. $\mathrm{T}_{0}$ generation of the putative transformants tested for incorporated genes by using polymerase chain reaction (PCR) and Southern hybridization techniques showed a transformation frequency of $70 \%$. The transformation efficiency is defined as the percentage of PCR-positive independent events from 100 putative events generated following antibiotic selection.

\section{Materials}

\subsection{Plant Material and Sterilization}

1. Chickpea seeds of the variety C-235 were obtained from the gene bank of the International Crops Research Institute for the Semi-Arid Tropics (ICRISAT).

2. $70 \%$ Ethanol.

3. $0.1 \%(\mathrm{w} / \mathrm{v})$ Aqueous mercuric chloride.

4. Sterile double-distilled water. 


\subsection{Plant Tissue Culture Stock Solutions and Media}

1. Murashige and Skoog's medium (MS): MS basal components (12), 3\% sucrose, $\mathrm{pH}$ adjusted to 5.8 prior to autoclaving.

a. Major salt (50X): prepare stock solutions of the major salts of MS medium as follows:

i. $\quad \mathrm{NH}_{4} \mathrm{NO}_{3}$ : dissolve $33 \mathrm{~g}$ of the chemical in $200 \mathrm{~mL}$ of sterile distilled water. Store the stock at room temperature for no more than 1 mo. Use $10 \mathrm{~mL}$ of the stock solution for preparing $1 \mathrm{~L}$ of the medium.

ii. $\mathrm{KNO}_{3}$ : dissolve $38 \mathrm{~g}$ of the chemical in $400 \mathrm{~mL}$ of sterile distilled water. Store the stock at room temperature for no more than $1 \mathrm{mo}$. Use $20 \mathrm{~mL}$ of the stock solution for preparing $1 \mathrm{~L}$ of the medium.

iii. $\mathrm{KH}_{2} \mathrm{PO}_{4}$ : dissolve $3.40 \mathrm{~g}$ of the chemical in $200 \mathrm{~mL}$ of sterile distilled water. Store the stock at room temperature for no more than $1 \mathrm{mo}$. Use $10 \mathrm{~mL}$ of the stock solution for preparing $1 \mathrm{~L}$ of the medium

iv. $\mathrm{CaCl}_{2}$ : dissolve $8.80 \mathrm{~g}$ of the chemical in $200 \mathrm{~mL}$ of sterile distilled water. Store the stock at room temperature for no more than $1 \mathrm{mo}$. Use $10 \mathrm{~mL}$ of the stock solution for preparing $1 \mathrm{~L}$ of the medium

v. $\mathrm{MgSO}_{4} \cdot 7 \mathrm{H}_{2} \mathrm{O}$ : dissolve $7.40 \mathrm{~g}$ of the chemical in $200 \mathrm{~mL}$ of sterile distilled water. Store the stock at room temperature for no more than 1 mo. Use $10 \mathrm{~mL}$ of the stock solution for preparing $1 \mathrm{~L}$ of the medium

b. Minor salts (100X): weigh the required quantities of the minor salts $(83 \mathrm{mg}$ $\mathrm{KI}, 2230 \mathrm{mg} \mathrm{MnSO} 4 \cdot \mathrm{H} 2 \mathrm{O}, 860 \mathrm{mg} \mathrm{ZnSO} \cdot \cdot 7 \mathrm{H}_{2} \mathrm{O}, 25 \mathrm{mg} \mathrm{Na} \mathrm{MoO}_{4} \cdot 2 \mathrm{H}_{2} \mathrm{O}$, $2.5 \mathrm{mg} \mathrm{CuSO}_{4} \cdot 5 \mathrm{H}_{2} \mathrm{O}, 2.5 \mathrm{mg} \mathrm{CoCl}_{2} \cdot 6 \mathrm{H}_{2} \mathrm{O}$ ) and dissolve in $100 \mathrm{~mL}$ of sterile distilled water. Store the stock $4^{\circ} \mathrm{C}$ for no more than $1 \mathrm{mo}$. Use $5 \mathrm{~mL}$ of the stock solution for preparing $1 \mathrm{~L}$ of the medium

c. Iron $(100 \mathrm{X})$ :

i. $\mathrm{Na}_{2}$ EDTA. $2 \mathrm{H}_{2} \mathrm{O}$ : dissolve $3.73 \mathrm{~g}$ of the chemical in $1000 \mathrm{~mL}$ of sterile distilled water. Store the stock at $4^{\circ} \mathrm{C}$ for no more than $1 \mathrm{mo}$. Use $5 \mathrm{~mL}$ of the stock solution for preparing $1 \mathrm{~L}$ of the medium.

ii. $\mathrm{FeSO}_{4} \cdot 7 \mathrm{H}_{2} \mathrm{O}$ : dissolve $2.78 \mathrm{~g}$ of the chemical in $1000 \mathrm{~mL}$ of sterile distilled water. Store the stock at $4^{\circ} \mathrm{C}$ for no more than 1 mo. Use $5 \mathrm{~mL}$ of the stock solution for preparing $1 \mathrm{~L}$ of the medium.

OR

iii. $\mathrm{FeNa}_{2}$ EDTA: dissolve $2 \mathrm{~g}$ of the chemical in $500 \mathrm{~mL}$ of sterile distilled water. Store the stock at $4^{\circ} \mathrm{C}$ for no more than 1 mo. Use $5 \mathrm{~mL}$ of the stock solution for preparing $1 \mathrm{~L}$ of the medium.

2. Kinetin (Sigma): $1 \mathrm{~m} M$ stock. Dissolve the $21.5 \mathrm{mg}$ of hormone powder in a few drops of $1 \mathrm{M} \mathrm{HCl}$ and make up the final volume using sterile distilled water. Store the stock at $-20^{\circ} \mathrm{C}$.

3. Indole-3-butyric acid (IBA; Sigma): $1 \mathrm{~m} M$ stock. Dissolve $20.3 \mathrm{mg}$ of the powder in a few drops of ethanol and adjust the final volume using sterile distilled water. Store at $-20^{\circ} \mathrm{C}$ for up to $3 \mathrm{mo}$. 
4. 2-Isopentenyladenine (2-iP): $1 \mathrm{~m} M$ stock. Dissolve $20.32 \mathrm{mg}$ of the chemical in a few drops of $1 \mathrm{~N} \mathrm{NaOH}$ and adjust the final volume by using sterile distilled water. Store at $-20^{\circ} \mathrm{C}$ for up to 3 mo.

5. Thidiazuron (TDZ): $1 \mathrm{~m} M$ stock. Dissolve $22.25 \mathrm{mg}$ of the powder in $100 \mathrm{~mL}$ of DMSO. Store at $-20^{\circ} \mathrm{C}$ for up to 3 mo.

6. Giberellic acid $\left(\mathrm{GA}_{3}\right): 1 \mathrm{~m} M$ stock. Dissolve $34.6 \mathrm{mg}$ of the powder in $100 \mathrm{~mL}$ of water. Store at $-20^{\circ} \mathrm{C}$ for up to 3 mo.

7. Shoot induction medium (SIM): MS medium, $4 \mu M$ TDZ, $10 \mu M$ 2-iP, $2 \mu M$ kinetin (adjust $\mathrm{pH}$ to 5.8 ), $0.8 \%$ agar for solidification.

8. Shoot elongation medium 1 (SEM1): MS medium, $5 \mu M$ 2-iP, $2 \mu M$ kinetin (adjust $\mathrm{pH}$ to 5.8 ), $0.8 \%$ agar.

9. Shoot induction medium 2 (SEM2): MS medium, $2 \mu M \mathrm{GA}_{3}$ (adjust $\mathrm{pH}$ to 5.8), $0.8 \%$ agar.

10. Cefotaxime: $125 \mathrm{mg} / \mathrm{mL}$ stock. Dissolve the powdered chemical in water and filter-sterilize the solution prior to use.

11. Kanamycin monosulfate (Sigma): $125 \mathrm{mg} / \mathrm{mL}$ stock. Dissolve the kanamycin in water. Filter-sterilize the stock and store in aliquots at $-20^{\circ} \mathrm{C}$ for no more than $15 \mathrm{~d}$.

\subsection{Bacterial Culture}

1. Agrobacterium strain and vector: disarmed Agrobacterium tumefaciens strain C58, harboring binary plasmids pBI121 with $n p t I I$ as a selectable marker gene.

2. Luria-Bertani medium (LB): $1 \%$ Bacto-tryptone, 0.5\% Bacto yeast extract, $1 \% \mathrm{NaCl}, 1.5 \%$ agar. Adjust the $\mathrm{pH}$ to 7.0 with $5 \mathrm{~N} \mathrm{NaOH}$ (approx $0.2 \mathrm{~mL}$ ) prior to autoclaving.

3. Yeast extract medium (YEB): $0.5 \%$ Bacto-peptone, $0.1 \%$ yeast extract, $0.5 \%$ beef extract, $0.5 \%$ sucrose, $0.05 \% \mathrm{MgSO}_{4} \cdot 7 \mathrm{H}_{2} \mathrm{O}$. Adjust $\mathrm{pH}$ to 7.0 with $\mathrm{NaOH}$ prior to autoclaving

\subsection{Root Induction and Hardening Conditions}

1. Root induction medium (RIM): modified MS medium with $9.4 \mathrm{mM}$ of $\mathrm{KNO}_{3}$, $5 \mu M$ IBA. Adjust the $\mathrm{pH}$ to 6.0 .

2. Hydroponics system: $\frac{1}{2}$ strength Arnon's nutrient solution, $\mathrm{pH} 6.5$ (13), $3 \mu M$ IBA in an 8-cm Magenta jar. Arnon's nutrient solution is composed of four different stock solutions of the major and minor salts.

a. Stock I: $12.2 \mathrm{~g}$ of $\mathrm{KH}_{2} \mathrm{PO}_{4}, 15.5 \mathrm{~g}$ of $\mathrm{KCl}, 25 \mathrm{~g}$ of $\mathrm{MgSO}_{4} \cdot 7 \mathrm{H}_{2} \mathrm{O}$. Dissolve the salts in $1000 \mathrm{~mL}$ sterile distilled water. Store the solution at room temperature for no more than $1 \mathrm{mo}$. Use $10 \mathrm{~mL}$ of this stock for preparing $1 \mathrm{~L}$ of the nutrient solution.

b. Stock II: $21.5 \mathrm{~g}$ of $\mathrm{CaCl}_{2} \cdot 2 \mathrm{H}_{2} \mathrm{O}$ or $25 \mathrm{~g}$ of $\mathrm{CaSO}_{4} \cdot 2 \mathrm{H}_{2} \mathrm{O}$. Dissolve the salts in $1000 \mathrm{~mL}$ sterile distilled water. Store the solution at room temperature for no more than $1 \mathrm{mo}$. Use $10 \mathrm{~mL}$ of this stock for preparing $1 \mathrm{~L}$ of the nutrient solution.

c. Stock III: $1 \mathrm{~g}$ of $\mathrm{MnSO}_{4} \cdot \mathrm{H}_{2} \mathrm{O}, 0.25 \mathrm{~g}$ of $\mathrm{ZnSO}_{4} \cdot 7 \mathrm{H}_{2} \mathrm{O}, 0.25 \mathrm{~g}$ of $\mathrm{CuSO}_{4} \cdot 5 \mathrm{H}_{2} \mathrm{O}$, $0.05 \mathrm{~g}$ of $\mathrm{Na}_{2} \mathrm{MO}_{4} \cdot 2 \mathrm{H}_{2} \mathrm{O}$. Dissolve the salts in $1000 \mathrm{~mL}$ sterile distilled water. 
Store the solution at room temperature for no more than $1 \mathrm{mo}$. Use $1 \mathrm{~mL}$ of this stock for preparing $1 \mathrm{~L}$ of the nutrient solution.

d. Stock IV: $30 \mathrm{~g}$ of $\mathrm{FeC}_{6} \mathrm{H}_{5} \mathrm{O}_{7} \cdot 5 \mathrm{H}_{2} \mathrm{O}$ or $15 \mathrm{~g}$ of $\mathrm{FeCl}_{3}$ or $59 \mathrm{~g}$ of NaFe-EDTA. Dissolve the salts in $1000 \mathrm{~mL}$ sterile distilled water. Store the solution at room temperature for no more than $1 \mathrm{mo}$. Use $1 \mathrm{~mL}$ of this stock for preparing $1 \mathrm{~L}$ of the nutrient solution.

\subsection{Transplantation}

1. Pots: 8- and 20-cm-diameter pots.

2. Fungicides: Thiram ${ }^{\circledR}$ and Bavistin ${ }^{\circledR}$.

3. Polypropylene bags.

4. Potting mixture: smooth and coarse sand and black farm soil (3:2), 10\% organic Cell $\mathrm{Rich}^{\circledR}$ and rice straw compost $(1: 1)$.

\section{Methods}

\subsection{Plant Material and Preparation of Explant}

1. Healthy and mature seeds of chickpea variety C-235, a widely grown cultivar, is used as starting material for subsequent procedures.

2. Surface-sterilize the seeds with $70 \%(\mathrm{v} / \mathrm{v})$ ethanol for $1 \mathrm{~min}$, followed by treating with $0.1 \%$ mercuric chloride for $10 \mathrm{~min}$. (Unless otherwise noted, all procedures are carried out under aseptic conditions.)

3. Rinse the seeds two to three times with sterile distilled water prior to soaking overnight.

4. Decoat the soaked seeds and place the seeds for germination on SIM at a density of 10 to 15 seeds per plate. Seal the plates with Parafilm. Allow the seedlings to grow at $26 \pm 1{ }^{\circ} \mathrm{C}$ under continuous light conditions $\left(60 \mu \mathrm{E} / \mathrm{m}^{2} / \mathrm{s}\right.$ light intensity provided by cool white fluorescent lamps) for 5 to $7 \mathrm{~d}$ until the axillary buds are prominent.

5. Carefully remove the axillary buds up to the base and make two cuts through the axillary meristem in order to remove the shoot and root tips up to the hypocotyl and epicotyl regions, respectively (Figs. 1 and $\mathbf{2 A}$ ).

6. Subculture the axillary meristem explants (AMEs) thus obtained on a plate containing SIM for another $7 \mathrm{~d}$ at $26 \pm 1{ }^{\circ} \mathrm{C}$ under continuous cool white light provided by fluorescent lamps $\left(60 \mu \mathrm{E} / \mathrm{m}^{2} / \mathrm{s}\right)$.

7. Carefully remove the emerging shoot buds from the enlarged base of the axillary bud (Figs. 1 and 2B) by scraping with a sharp scalpel blade to obtain the explant (AM4) for transformation purposes (Figs. 1 and 2C).

\subsection{Agrobacterium Culture Preparation and Explant Infection}

1. Inoculate a single colony of A. tumefaciens strain C58 harboring the gene of interest in $25 \mathrm{~mL}$ YEB liquid medium containing appropriate antibiotics and allow to grow overnight at $28^{\circ} \mathrm{C}$ on an incubator-shaker.

2. Ensure that the OD of the overnight grown culture is between 0.6 and 1.0.

3. Divide the culture into two $(12 \mathrm{~mL}$ culture per tube) in $25-\mathrm{mL}$ centrifuge tubes. Centrifuge at $600 \mathrm{~g}$ for $5 \mathrm{~min}$. 


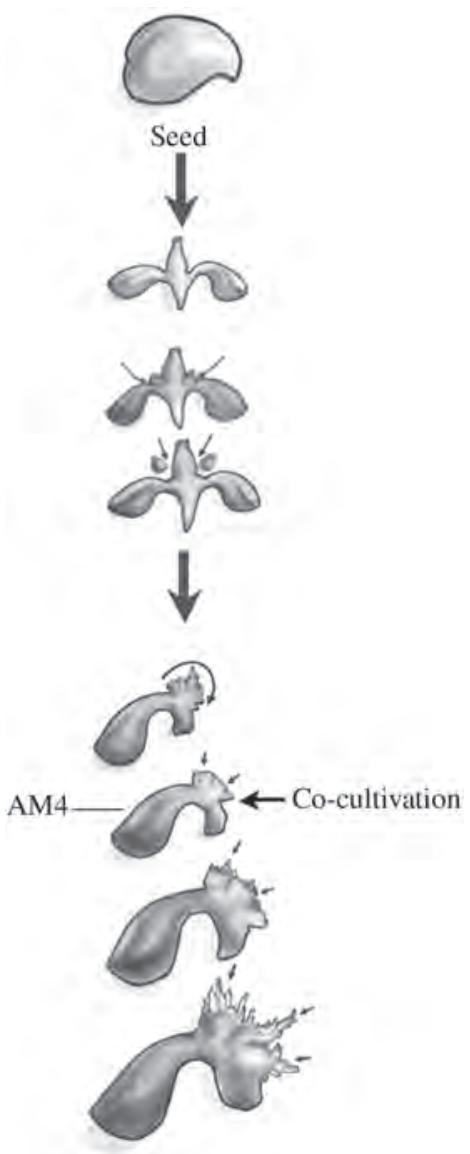

Fig. 1. Diagramatic representation of the preparation of axillary meristem explants (AM4) of chickpea for Agrobacterium-mediated genetic transformation. Large arrows depict the progression of explant preparation. Medium and circular arrows indicate sites of surgery, and small arrows show sites of multiple shoot regeneration.

4. Discard the supernatant carefully and wash the pellet with $10 \mathrm{~mL}$ of sterile $1 / 2$ strength MS medium.

5. Centrifuge the cells at $600 \mathrm{~g}$ for 2 to $3 \mathrm{~min}$ to collect the cell pellet.

6. Resuspend the pellet in $25 \mathrm{~mL}$ of sterile $1 / 2 \mathrm{MS}$ and pour in a sterile Petri plate for infecting the prepared explants.

7. Briefly dip the explants (AM4; Figs. 1 and 2C) in the Agrobacterium culture for 1 to $2 \mathrm{~s}$ and culture five to seven explants on SIM with the base of the cotyledon embedded in the medium.

8. Cocultivate the explants with the bacteria for $48 \mathrm{~h}$, at $26 \pm 1{ }^{\circ} \mathrm{C}$ under continuous cool white light provided by fluorescent lamps $\left(60 \mu \mathrm{E} / \mathrm{m}^{2} / \mathrm{s}\right)$. 

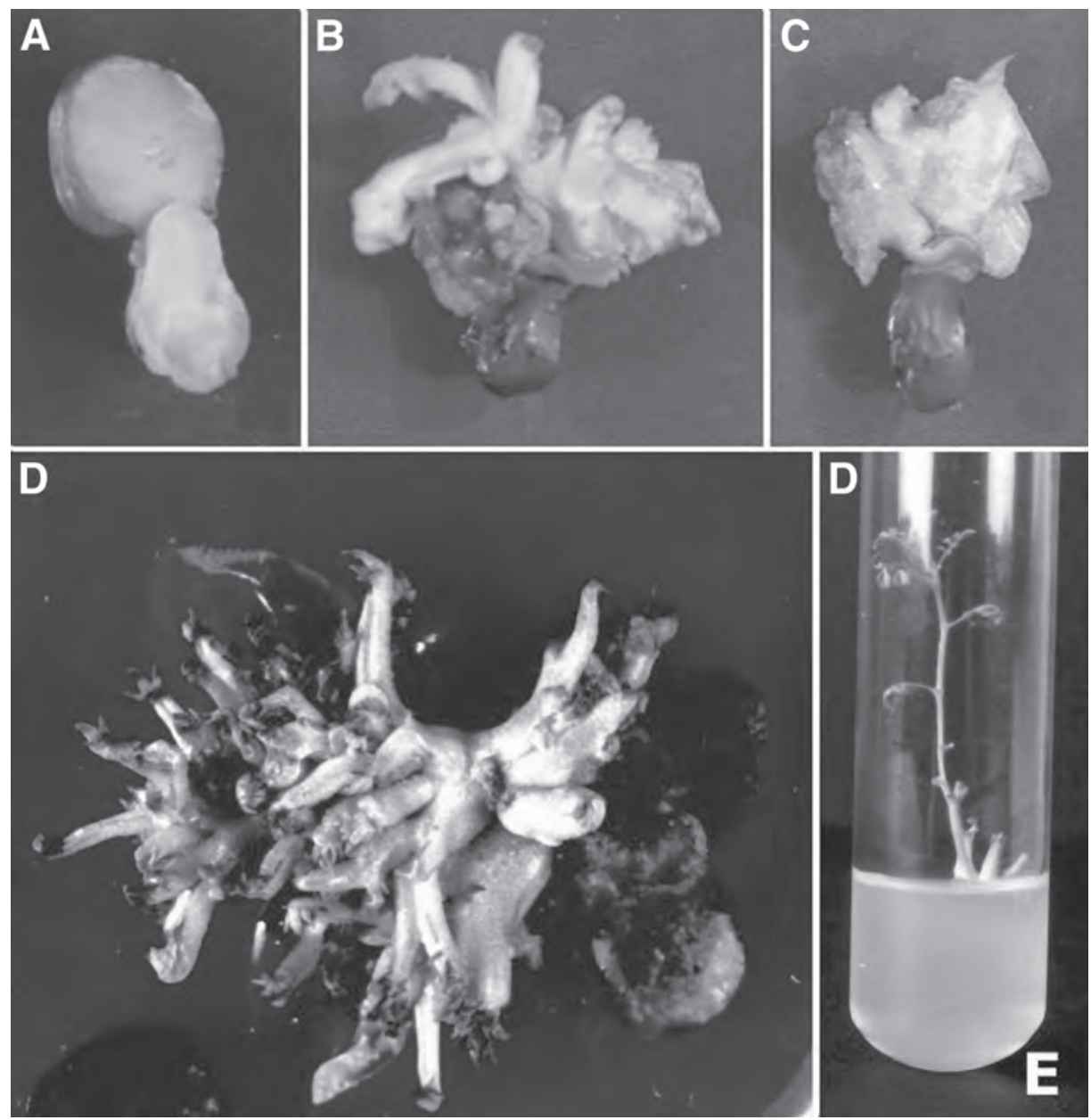

Fig. 2. Regeneration of adventitious shoot buds and plants from axillary meristem explants of chickpea. (A) Axillary meristem explant derived from presoaked chickpea seeds. (B) Regeneration of multiple shoot buds from AME after $5 \mathrm{~d}$ of culture on SIM. (C) Explant containing swollen area after removal of regenerating shoot buds (AM4) after $7 \mathrm{~d}$ of culture on SIM. (D) Multiple shoots originating from different parts of regenerating area after 12 to $14 \mathrm{~d}$ of culture on MS. (E) Elongation of shoots on SEM after 1 to $2 \mathrm{wk}$ of culture.

\subsection{Regeneration and Multiplication of Shoots}

1. After cocultivation, transfer the explants to MS medium containing $250 \mathrm{mg} / \mathrm{L}$ cefotaxime for 4 to $5 \mathrm{~d}$ at $26 \pm 1{ }^{\circ} \mathrm{C}$ under continuous cool white light provided by fluorescent lamps $\left(60 \mu \mathrm{E} / \mathrm{m}^{2} / \mathrm{s}\right)$. 
2. Transfer the explants onto MS medium containing $250 \mathrm{mg} / \mathrm{L}$ cefotaxime and a low selection pressure (e.g., $25 \mathrm{mg} / \mathrm{L}$ kanamycin or $2 \mathrm{mg} / \mathrm{L}$ hygromycin) for 1 wk under the same culture conditions (see Note 1).

3. Subculture the explants containing multiple shoot buds (Fig. 2D) on MS medium containing a relatively higher selection pressure $(50 \mathrm{mg} / \mathrm{L}$ kanamycin or $5 \mathrm{mg} / \mathrm{L}$ hygromycin) for 7 to $10 \mathrm{~d}$ (see Note 2).

4. Carefully separate the bunches of emerging shoot buds from the cotyledon part with some intact basal callus and transfer to shoot elongation medium (SEM1) containing a higher selection pressure $(75 \mathrm{mg} / \mathrm{L}$ kanamycin or $7.5 \mathrm{mg} / \mathrm{L}$ hygromycin) for another $10 \mathrm{~d}$ (Fig. 2C).

5. Transfer the elongated (Fig. 2E) as well as unelongated shoots to SEM2 containing a stringent selection pressure (100 mg/L kanamycin or $10 \mathrm{mg} / \mathrm{L}$ hygromycin) for two to three passages at 7-d intervals.

6. Carefully separate the healthy growing shoots from the elongating shoot bunch, and remove the untransformed bleached shoots.

7. Replace the stunted shoots on SEM 2 for two to three passages of $1 \mathrm{wk}$ each for further elongation and increasing the length of internodes (see Note 3).

\subsection{Rooting of Shoots}

1. Phase 1: select dark green, healthy shoots approx $5 \mathrm{~cm}$ long for induction of adventitious roots. Cut the basal stem segment of the elongated shoot in half so it does not contain any nodal meristem, and culture it on a filter paper bridge immersed in root induction medium (RIM) for 1 to 2 wk (Fig. 3A; see Notes 4-6).

2. Phase 2: pulse treat the shoots that fail to form roots within 1 to 2 wk by dipping the shoots in $100 \mu M$ IBA followed by culturing on filter papers immersed in the liquid MS medium.

3. Phase 3: use a hydroponic system for inducing roots in the shoots that do not root even after two to three subcultures on RIM. Fill 8-cm-diameter Magenta jars with $1 / 2$ strength Arnon's solution containing $3 \mu M$ IBA and suspend the shoot with a support such that $1 \mathrm{~cm}$ of the shoot base is immersed in the solution (Fig. 3B). Change the media after every 4 to $5 \mathrm{~d}$ until the root primordia appears. Transfer the shoots with roots to hormone-free Arnon's solution for further growth and development.

\subsection{Hardening and Transplantation of Rooted Shoots}

1. Take the plants out of the tubes carefully, wash the roots thoroughly, dip in $0.5 \%$ Thiram solution, and transfer each of the rooted shoots to 8 -cm-diameter pots containing 2 to $4 \mathrm{~mm}$ of sand (Fig. 3C). Water the pot optimally, cover the plants completely with polypropylene bags, and gradually open the covers over 7- to 10-d period (see Note 7).

2. Transfer the hardened plants to $20-\mathrm{cm}$-diameter pots containing the potting mixture. 

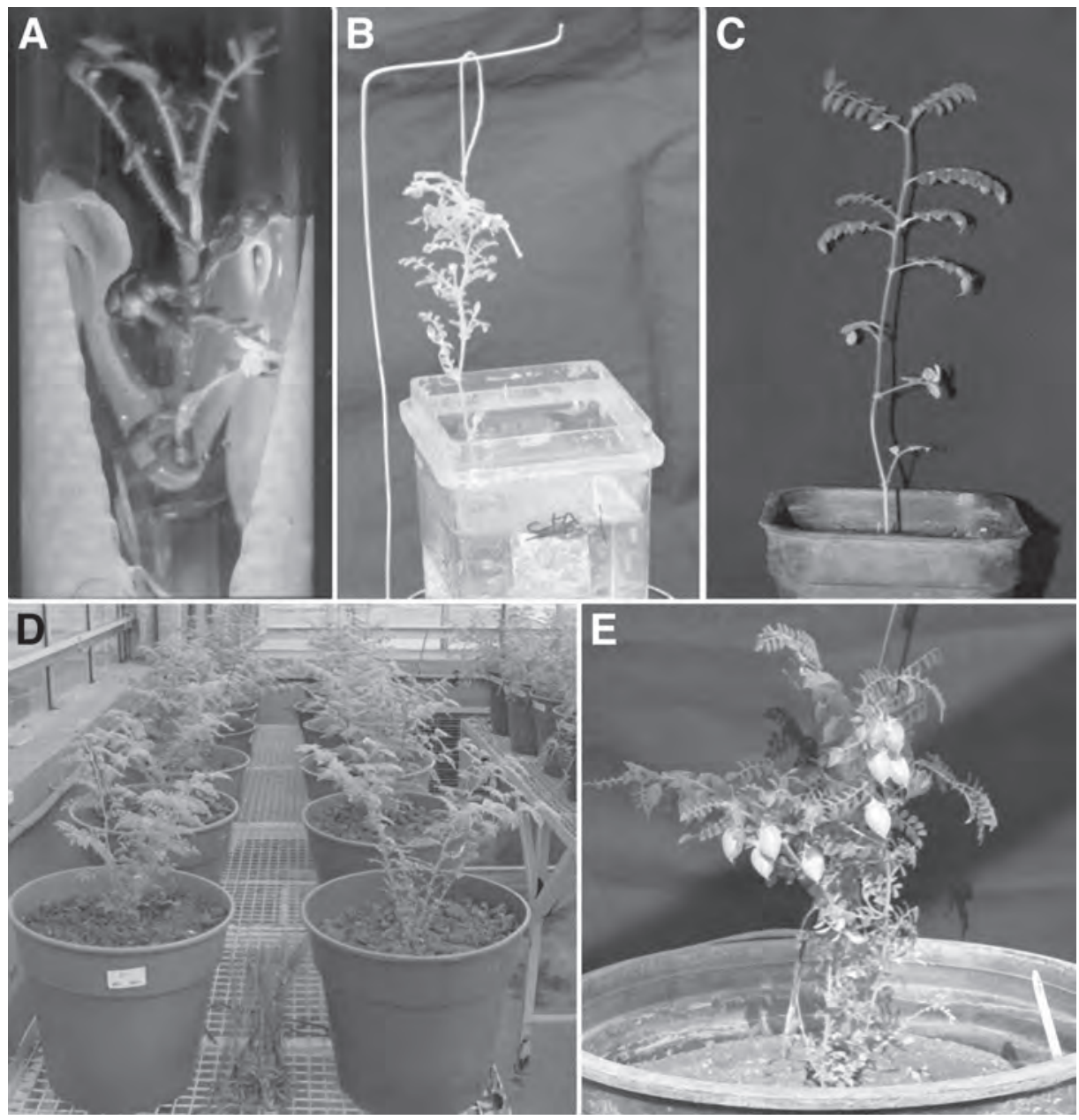

Fig. 3. Rooting, hardening, and transplantation of in vitro regenerated chickpea plants. (A) Rooting of elongated shoot on a filter paper bridge soaked in RIM. (B) Hardening of rooted plantlets in a hydroponic system. (C) Transplanted chickpea plant after hardening for 10 to $12 \mathrm{~d}$ as in (B). (D) Hardened and transplanted chickpea plants growing in greenhouse conditions. (E) Mature chickpea plant bearing pods containing viable seeds at the time of harvest after $100 \mathrm{~d}$ of transplantation.

\subsection{Maintenance of Plants in the Greenhouse and Seed Production}

1. Transfer the plants to a containment greenhouse with $24 / 18^{\circ} \mathrm{C}$ day/night temperatures and allow these to grow (Fig. 3D) until maturity and subsequent progression of generations $\left(\mathrm{T}_{1}, \mathrm{~T}_{2}\right.$, and so on). Normally it takes approx $100 \mathrm{~d}$ from transplantation for the plants to mature for harvesting (Fig. 3E). 
2. Remove the terminal buds of some branches and remove the emerging flowers to extend the vegetative growth of the plant.

3. Harvest the seeds as soon as the pods turn yellow to yellowish brown in color; this can also be postponed until the mother plant is completely dry. The typical seed set rate is approx 45 to 55 seeds per plant.

\subsection{Characterization of Putative Transformants}

1. Carry out extraction of genomic DNA using young leaflets of the putative transformants following the protocol of Dellaporta et al. (14). Typically $1 \mathrm{~g}$ of fresh young leaflets results in approx 50 to $60 \mu \mathrm{g}$ of genomic DNA.

2. Use approx $200 \mathrm{ng}$ of purified DNA for a PCR amplification reaction using standard procedures followed by assay of PCR products on $1.2 \%$ agarose gels.

3. For Southern blot hybridization, we typically use 10 to $15 \mu \mathrm{g}$ of total DNA and digest it with appropriate restriction enzymes that cut only once on T-DNA. The digested DNAs are resolved on $0.8 \%$ agarose gel, blotted onto a nylon membrane, and hybridized with gene-specific probes (radioactive or nonradioactive) following the standard protocol (15).

4. Carry out genetic analysis to ascertain the inheritance pattern of the introduced genes in the $T_{1}$ generation progenies of primary transformants. This is done by growing all the progenies of the selected events (primary positively confirmed transformants) and then carrying out PCR analysis on the genomic DNA for the introduced genes. The segregation of a single-copy insert usually follows a Mendelian inheritance pattern of 3:1 (i.e., 3 positives to 1 negative progeny). In the case of chickpea, selection of the seedlings on kanamycin- or hygromycin-containing medium is not very reliable.

\section{Notes}

1. A progressive selection system with stepwise increases in the concentration of the selective agent at each stage has been found to be useful in obtaining stringently selected putative transformants in chickpea.

2. The bleached shoots must be carefully removed at each stage to prevent escapes.

3. Subculture of stunted shoots on SEM2 for one to two extra passages increases the frequency of elongation and the length of the internodes.

4. Imposition of any selection pressure must be avoided at the rooting stage as it decreases the rooting frequency.

5. Inclusion of any nodal meristem on the surface exposed to rooting medium drastically reduces the rooting frequency of the shoots.

6. Use of filter paper bridges for rooting is beneficial, as it prevents the shoots from desiccating, resulting in efficient rooting of the shoots.

7. The rooted shoots should ideally be transferred to the hardening phase within $10 \mathrm{~d}$ of the root primordia being observed. 


\section{References}

1. Rao, B. G. (1990) Regeneration from induced embryoids of gram (Cicer arietinum L.). Adv. Plant Sci. 3, 299-302.

2. Rao, B. G. (1991) Influence of explant and its stages of development on response for somatic embryogenesis in chickpea. Adv. Plant Sci. 4, 43-47.

3. Sonia, Singh, R. P., Sharma, K. K., and Jaiwal, P. K. (2003). In vitro regeneration and genetic transformation of chickpea, in Applied Genetics of Leguminosae Biotechnology (Jaiwal, P. K. and Singh, R. P., eds.), Kluwer Academic Publishers, Dordrecht, pp. 69-87.

4. Rao, B. G. and Chopra, V. L. (1989) Regeneration in chickpea (Cicer arietinum L.) through somatic embryogenesis. J. Plant Physiol. 134, 637-638.

5. Barna, K. S. and Wakhlu, A. K. (1993) Somatic embryogenesis and plant regeneration from callus 1 cultures of chickpea (Cicer arietinum L.). Plant Cell Rep. $12,521-524$.

6. Suhasini, K., Sagare, A. P., and Krishnamurthy, K. V. (1994) Direct somatic embryogenesis from mature embryo axis in chickpea (Cicer arietinum L.). Plant Sci. 102, 189-194.

7. Prakash, S., Chowdhury, J. B., Yadav, N. R., Jain, R. K., and Chowdhury, V. K. (1993) Somatic embryogenesis in suspension cultures of chickpea. Ann. Biol. 10, $7-14$.

8. Fontana, G. S., Santini, L., Caretto, S., Frugis, G., and Mariotti, D. (1993) Genetic transformation in the grain legume Cicer arietinum L. (chickpea). Plant Cell Rep. 12, 194-198.

9. Kar, S., Basu, D., Das, S., et al. (1997) Expression of Cry1A(c) gene of Bacillus thuringensis in transgenic chickpea plants inhibits development of pod borer (Heliothis armigera) larvae. Transgenic Res. 6, 177-185.

10. Krishnamurthy, K. V., Suhasini, K., Sagare, A. P., et al. (2000) Agrobacteriummediated transformation of chickpea (Cicer arietinum L.), embryo axes. Plant Cell Rep. 19, 235-240.

11. Jayanand, B., Sudarsanam, G., and Sharma, K. K. (2003). An efficient protocol for the regeneration of whole plants of chickpea (Cicer arietinum L.) by using axillary meristem explants derived from in vitro germinated seedlings. In Vitro Cell. Dev. Biol. Plant 39, 171-179.

12. Murashige, T. and Skoog (1962) A revised medium for rapid growth and bioassay with tobacco tissue cultures. Physiol. Plant 15, 473-497.

13. Arnon, D. F. (1938) Microelements in culture solution experiment with higher plants. Am. J. Bot. 25, 322-325.

14. Dellaporta, S. L., Wood, L., and Hicks, J. B. (1983) A plant DNA minipreparation: version II. Plant Mol. Biol. Rep. 1, 19-21.

15. Sambrook, J., Fritsch, E. F., and Maniatis, T. (1989) Molecular Cloning: A Laboratory Manual. Cold Spring Harbor Laboratory Press, Cold Spring Harbor, NY. 
